\title{
FRUCTOSE MALABSORPTION IN CHILDREN WITH FUNCTIONAL DIGESTIVE DISORDERS
}

\author{
Adriana Chebar LOZINSKY, Cristiane BOÉ, Ricardo PALMERO and \\ Ulysses FAGUNDES-NETO
}

\begin{abstract}
Context - Fructose is a monosaccharide frequently present in natural and artificial juice fruits. When the concentration of fructose in certain food is present in excess of glucose concentration some individuals may develop fructose malabsorption. Objectives - To report the frequency of fructose malabsorption utilizing the hydrogen breath test in children with gastrointestinal and/ or nutritional disorders. Methods - Between July 2011 and July 2012, 43 patients with gastrointestinal and/or nutritional disorders, from both sexes, were consecutively studied, utilizing the hydrogen breath test with loads of the following carbohydrates: lactose, glucose, fructose and lactulose. Fructose was offered in a $10 \%$ aqueous solution in the dose of $1 \mathrm{~g} / \mathrm{kg}$ body weight. Samples were collected fasting and at every 15 minutes after the intake of the aqueous solution for a 2 hour period. Malabsorption was considered when there was an increase of $>20 \mathrm{ppm}$ of hydrogen over the fasting level, and intolerance was diagnosed if gastrointestinal symptoms would appear. Results - The age of the patients varied from 3 months to 16 years, 24 were boys. The following diagnosis were established: irritable bowel syndrome with diarrhea in 16 , functional abdominal pain in 8 , short stature in 10 , lactose intolerance in 3 , celiac disease in 1, food allergy in 1 and giardiasis in 1 patient. Fructose malabsorption was characterized in $13(30.2 \%)$ patients, and intolerance in $1(2.3 \%)$ patient. The most frequent fructose malabsorption was characterized in $7(16.3 \%)$ patients with irritable bowel syndrome and in $4(9.3 \%)$ patients with functional abdominal pain. Conclusions - Patients with irritable bowel syndrome and functional abdominal pain were the main cause of fructose malabsorption.
\end{abstract}

HEADINGS - Fructose, deficiency. Intestinal absorption. Breath test. Child.

\section{INTRODUCTION}

Fructose is a monosaccharide found in nature mostly as a component of sucrose. Fructose has been frequently utilized in the western countries diet as a sweetener in industrialized products, since it is a cheaper alternative compared with sucrose. Fructose is frequently present in sodas, candies and mainly in natural and artificial juice fruits ${ }^{(16)}$. Fructose is transported through the intestinal epithelium by a facilitative transport system designated GLUT5, which has high fructose affinity that carries this monosaccharide through the apical membrane of the enterocyte ${ }^{(13)}$. This mechanism has a limited absorption capacity for fructose. Another pathway of fructose absorption occurs when it is ingested with glucose, by the mechanism called solvent drag, through the tight junctions of the enterocytes ${ }^{(24)}$.

When the concentration of fructose in a certain food is present in excess of glucose concentration, condition very frequently observed in various juice fruits, mainly in apple, pear and grape juices, some individuals may develop fructose malabsorption ${ }^{(2-15,20)}$.
These individuals may present several symptoms that include flatulence, diarrhea, abdominal pain and abdominal distension. To establish the diagnosis of fructose malabsorption/intolerance a detailed dietary story should be obtained associated to laboratory investigation that can be performed utilizing the hydrogen breath test (HBT) ${ }^{(5)}$. Under this circumstance when the monosaccharide is not absorbed in the small intestine it is fermented by the colonic bacteria thereby producing gases like methane, carbon dioxide, hydrogen (H2) and even short chain fatty acids, such as acetic, butiric and propionic acids. $\mathrm{H} 2$ diffuses across the colonic mucosa, dissolves into the systemic circulation and circulates through the lungs. It then can be measured noninvasively in collected samples of expired breath after the ingestion of a fructose load. The diagnosis is confirmed when there are the relief of the symptoms after fructose is eliminated from the diet.

The aim of the present study is to report the frequency of fructose malabsorption utilizing the HBT in patients with gastrointestinal and nutritional disorders. 


\section{METHODS}

\section{Patients}

Forty three patients, of both sexes ( 24 boys), aging 3 months to 16 years, median 2.6 years, were consecutively and prospectively investigated, recruited from the Federal University of Sao Paulo (UNIFESP) Pediatric Gastroenterology outpatient clinic, presenting clinical complains of gastrointestinal and/or nutritional disorders, such as: chronic abdominal pain, chronic diarrhea and failure to thrive, during the period from July 2011 through July 2012.

The patients were divided in two groups according the major complains, as follows: 1- irritable bowel syndrome (IBS): 16 patients; 2- Other digestive and/or nutritional symptoms: failure to thrive (FT) 10, food allergy 4, lactose intolerance 3, celiac disease (CD) 1 and giardiasis 1 patient.

All the patients underwent the HBT utilizing the following carbohydrates: glucose, fructose, lactose and lactulose, as part of the routine of the investigation of the digestive/ absorptive function.

Other pertinent laboratorial tests considering the specific demand of each case were also performed.

\section{Hydrogen breath test}

The tests were individually performed for each carbohydrate in subsequent days.

After an overnight fasting the patients ingested an oral carbohydrate load in a $10 \%$ aqueous solution, in the following doses: lactose $2 \mathrm{~g} /$ body weight (maximum 25 grams), glucose and fructose $1 \mathrm{~g} /$ body weight (maximum 12 grams) and lactulose 20 grams.

The expired breath samples were collected in the fasting state to measure the $\mathrm{H} 2$ baseline value. After the ingestion of the carbohydrate load breath samples were collected every 15 minutes during the first hour and every 30 minutes in the second hour of the test, in order to complete in total 2 hours for each test.

\section{Interpretation criteria of Hydrogen breath test}

When the tests were performed with lactose, glucose and fructose load a rise in breath $\mathrm{H} 2$ of at least $20 \mathrm{ppm}$ above the baseline was interpreted as a positive test result (malabsorption). Intolerance was diagnosed if the patient would have shown during the performance of the test and/or up to 8 hours after the test had been performed the patient had presented abdominal distension, abdominal pain and/ or diarrhea.

On the other hand when the test was performed with lactulose if there was a rise in the breath $\mathrm{H} 2$ of at least $20 \mathrm{ppm}$ above the baseline in the first 60 minutes after the ingestion of the carbohydrate load bacterial overgrowth in the small intestine was diagnosed.

\section{Definitions}

The diagnosis of functional disorders was characterized according to the Rome III criteria ${ }^{(19)}$, as follows:

1. IBS: abdominal discomfort or pain, at least once per week for at least 2 months before diagnosis, associated with two or more of the following symptoms: improved with defecation, onset associated with change in frequency of stool, onset associated with a change in form of stool, no evidence of the coexistence of an inflammatory, neoplastic, anatomic or metabolic process that could explain the symptoms.

2. Functional abdominal pain (FAP): episodic or continuous abdominal pain, at least one per week for at least 2 months before diagnosis, with no evidence of the coexistence of an inflammatory, neoplastic, anatomic or metabolic process that could explain the symptoms.

3. FT: characterized when height for age was below 2 standard deviation utilizing the z-score as a pattern of reference ${ }^{(18)}$.

4. CD: characterized according to ESPGHAN criteria ${ }^{(20)}$.

Informed parental consent was obtained for the performance of the diagnostic tests.

The present study was approved by the Ethic Committee of the EPM/UNIFESP.

\section{RESULTS}

Fructose malabsorption was characterized in $13(30.2 \%)$ patients, and $1(2.3 \%)$ patient also revealed fructose intolerance within the first 8 hours after the performance of the test. Figure 1 depicts a characteristic fructose malabsorption test, showing the $\mathrm{H} 2$ peak in the expired breath above $20 \mathrm{ppm}$ of the baseline, and as a matter of comparison of the graphic lines it is also shown a normal test.

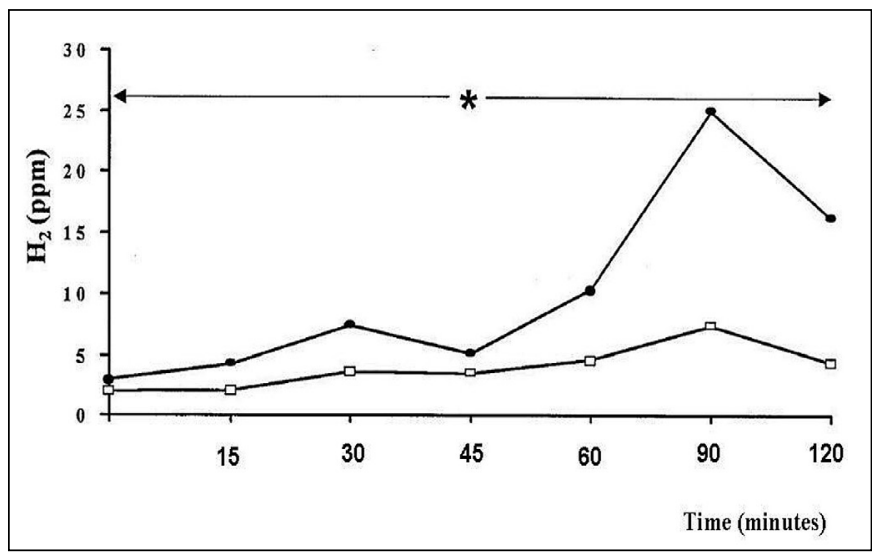

FIGURE 1. Graphic representation of the fructose load test showing an abnormal $\mathrm{H} 2$ concentration in the expired air above 20 ppm over the basal value, in comparison with a normal test

Figure 2 shows the 13 patients that presented fructose malabsorption associated with their respective diagnosis, as follows: IBS 7, FAP 4, FT 1 and CD 1 patient.

The analysis of the HBT utilizing the other carbohydrates (lactose, glucose and lactulose) showed the following results: lactose malabsorption 3, bacterial overgrowth syndrome in the small bowel 1. All the tests utilizing the glucose load showed normal results. 


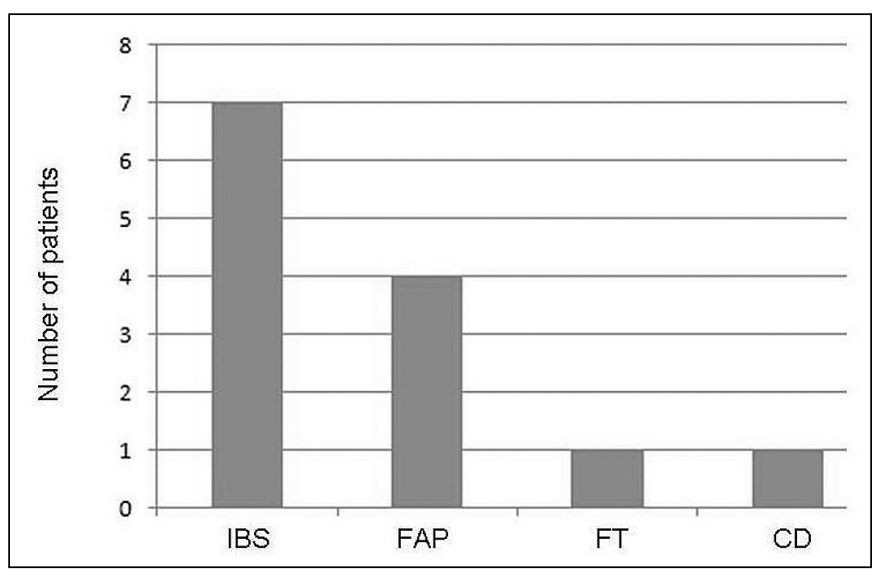

FIGURE 2. Graphic representation of the frequency of fructose malabsorption of the studied patients and their respective diagnosis

\section{DISCUSSION}

Historically, fruit juice has been recommended by pediatricians as a source of vitamin $C$ and an extra source of water for healthy infants and young children as their diets expanded to include solid foods with higher renal solute. In 1997, US consumers spent almost US\$ 5 billion on refrigerated and bottled juice. Mean juice consumption in USA reached the value of 40 billions/liter/year, something around 200 liters/ per capita. Children were the single largest group of juice consumers, and those younger than 12 years account for $28 \%$ of all juice fruit consumed ${ }^{(1)}$. Although these data are not available in Brazil, it is reasonable to presume that due to the similar cultural habits currently present in the western world, considering this nutritional aspect, those values might be very close to those observed in the USA. In Brazil, not a long time ago, orange juice was the most frequent juice offered to our children; however, due to the large diversification of the food industry, other juice fruits, such as, grape, apple and pear, were introduced in the regular diet of the Brazilian children. Water is the predominant component of fruit juice, however, the carbohydrate, including, sucrose, fructose, glucose and sorbitol, are the next most prevalent nutrient in juices. The carbohydrate concentration varies from $11 \mathrm{~g} / 100 \mathrm{~mL}(0.44$ $\mathrm{kcal} / \mathrm{mL}$ ) to more than $16 \mathrm{~g} / \mathrm{mL}(0.64 \mathrm{kcal} / \mathrm{mL})^{(3)}$. Sucrose is a disaccharide that is hydrolyzed into their monosaccharide components, glucose and fructose, due to the action of a disaccharidase, namely sucrase, present in the microvilli of the enterocytes. Glucose absorption is due to an active transport mechanism, while fructose is transported across the intestinal epithelium by facilitative transporters, but it can only move down a concentration gradient. Moreover, fructose may be more efficiently absorbed when glucose is present in equimolar concentrations. When the concentration of fructose exceeds the glucose concentration malabsorption of fructose may occur ${ }^{(17,19,21-25)}$. It is well known that the absorptive capacity of the small intestine for fructose is limited. In addition, glucose facilitates fructose absorption by solvent drag and passive diffusion ${ }^{(24)}$. Therefore, foods that contain equimolar concentrations of glucose and fructose may result in better fructose absorption than foods in which fructose exceeds glucose. Apple, grape and pear juices present fructose concentration that exceeds more than the double of glucose concentration, while orange juice shows an equivalent concentration of fructose and glucose ${ }^{(15)}$. Fructose malabsorption has increasingly been reported as another cause to be aggregated to patients that complain from gastrointestinal symptoms. Previous studies of the relation between fructose malabsorption and abdominal symptoms have been done in adults. Choi et al. ${ }^{(2)}$ studied 183 patients with the fructose breath test, using 50 grams of fructose as a $33 \%$ aqueous solution, and observed a positive result in $73 \%$ of this group. These patients also reported symptoms, such as, abdominal pain, flatulence, flatus, belching and diarrhea. Adult patients with IBS and fructose malabsorption had worse symptoms than did IBS without fructose malabsorption ${ }^{(23)}$. Recent studies with adult patients showed that a significant number of patients with fructose malabsorption reported relief of the gastrointestinal symptoms when they used a fructose restricted diet ${ }^{(11-14)}$.

It is well established that the $\mathrm{H} 2$ breath test shows high sensitivety and specificity ${ }^{(22)}$. In the past, the lungs were believed to be an organ responsible only for breathing, and therefore, there was a concept that only oxygen and carbon dioxide were measurable in the expired breath. At present it is known that the expired breath contains more than 2,000 different substances and besides breath function the lungs have an additional activity, which is the excretion of volatile substances, $\mathrm{H} 2$ being one of them. Healthy human beings in the fasting state and at rest do not excrete $\mathrm{H} 2$ because the metabolism does not produce this gas. $\mathrm{H} 2$ is basically generated by the anaerobic metabolism of the colonic flora. The anaerobic bacteria have a preferential trend to metabolize the carbohydrates, which are fermented resulting in short chain fatty acids, $\mathrm{CO} 2$ and $\mathrm{H} 2 . \mathrm{H} 2$ is produced in the intestine, crosses the intestinal wall, goes to the systemic circulation, it is transport to the lungs, and finally is eliminated through the expired breath. $\mathrm{H} 2$ concentration can be measured in parts per million in the expired air utilizing a non invasive technique with a high precision index ${ }^{(6)}$.

The proportion of malabsorption on the fructose breath test is dependent on the dose of fructose given. This effect has been more extensively studied in adults than in children; in healthy adults, $58 \%$ to $87 \%$ tested positive by the breath test when given a 50 grams dose of fructose, $10 \%$ to $53 \%$ tested positive with a 25 grams dose, and $0 \%$ to $10 \%$ with a 15 grams dose ${ }^{(4)}$. In healthy children, the effect of fructose dose on malabsorption has been shown in 0.1 to 6 year-olds; of whom $100 \%$ tested positive when challenged with a $2 \mathrm{~g} / \mathrm{bw}$ dose, reducing to $44 \%$ positive with a $1 \mathrm{~g} / \mathrm{bw} \operatorname{dose}^{(9)}$. In the present study we utilized the standardized dose of $1 \mathrm{~g} / \mathrm{bw}$ up to a maximum 12 grams, which can be considered relatively low in comparison with the volume potentially ingested with the daily diet, since a glass of apple juice $(200 \mathrm{~mL})$ contains approximately 15.5 grams of fructose (6.8 grams of glucose and 3 grams of sucrose $)^{(10)}$. This fact may explain 
why although we had detected fructose malabsorption in 13 $(30.5 \%)$ patients, only one of them had notorious fructose intolerance, with abdominal distension and diarrhea.

Recently, Jones et al. reported fructose malabsorption in children with gastrointestinal symptoms, mainly diarrhea and abdominal pain ${ }^{(12)}$. Jones et al emphasized that fructose consumption in excess of a normal threshold for absorption may have the same effects as a lower level of fructose consumption in excess of a lowered threshold for fructose absorption. The results of the present study are similar to Jones et al findings, since the majority of the 13 patients with fructose malabsorption, 7 of them suffered from IBS with diarrhea and 4 suffered from FAP. It is important to refer that Gomara et al. also reported fructose intolerance in children presenting with $\mathrm{FAP}^{(8)}$. These patients showed relief of the pain when a fructose restricted diet was introduced. Gomara et al demonstrated that 11 out of 33 patients with FAP presented fructose malabsorption test and even more they were able to reproduce the gastrointestinal symptoms of fructose malabsorption in 9 out of 11 patients. The restriction of fructose in the diet of these patients resulted in a significant relief of the symptoms during the 2 months the patients were followed up. Gomara et al. emphasized that their findings support the recommendation of fructose restriction as an easily implement therapy in children that can result in a decrease in gastrointestinal symptoms.

Gijsbers et al.(7) investigated malabsorption of lactose and fructose as causes of FAP in a group of 220 children (128 girls, mean age 8 , years) utilizing the HBT with lactose load in 210 patients and fructose load in 121 patients. Mal- absorption of lactose was found in $57(27.0 \%)$ of 210 and of fructose in $79(65.0 \%)$ of 121 patients. Pain disappeared upon elimination of lactose from the diet in 24/38 patients with lactose malabsorption and upon elimination of fructose from the diet in 32/49 with fructose malabsorption. Open provocation with lactose and fructose was positive in $7 / 23$ and $13 / 31$, respectively. It is important to state that this high prevalence of lactose and fructose malabsorption reported by Gijbers et al. may be due to an excessive dose of both carbohydrates utilized in the load test. The authors utilized a dose of $2 \mathrm{~g} / \mathrm{bw}$ in a $16.7 \%$ concentration of solution, therefore above the international standardized dose of $1 \mathrm{~g} / \mathrm{bw}$ for fructose load in a $10 \%$ aqueous solution, which was utilized in our study.

In conclusion, in the present study we were able to characterize fructose malabsorption in $30.2 \%$ of the patients with several different gastrointestinal and/or nutritional disorders, and one $(2.3 \%)$ of them showed fructose intolerance. IBS was the most important cause of the high prevalence of fructose malabsorption followed by FAP; however in almost all patients there were no symptoms of intolerance, and this was probably due to a mechanism of colonic compensation.

\section{ACKNOWLEDGEMENTS}

The authors wish to thank the excellent secretariat assistance of Mrs. Tatianne Rocha.

\section{Sources of funding}

UFN is recipient of a Research Grant from Conselho Nacional de Pesquisa (CNPQ) number 304.150/2009/6.

Lozinsky AC, Boé C, Palmero R, Fagundes-Neto U. Má absorção à frutose em crianças com transtornos digestivos funcionais. Arq Gastroenterol. 2013,50(3):226-30.

RESUMO - Contexto - Frutose é um monossacarídeo frequentemente presente em sucos de frutas naturais e artificiais. Quando a concentração de frutose em determinados alimentos está presente em excesso de glicose, alguns indivíduos podem apresentar má absorção à frutose. Objetivo - Descrever a freqüência de má absorção à frutose utilizando o teste do hidrogênio no ar expirado em crianças com transtornos digestivos e/ou nutricionais. Métodos - Durante o período compreendido entre julho de 2011 e julho de 2012 foram investigados de forma consecutiva 43 pacientes, de ambos os sexos, com suspeita de má absorção, por meio do teste hidrogênio no ar expirado com sobrecarga dos seguintes carboidratos: lactose, glicose, frutose e lactulose. A frutose foi administrada em solução aquosa $10 \%$ à dose de $1 \mathrm{~g} / \mathrm{kg}$ de peso. Foram obtidas amostras em jejum e, após a ingestão da solução, a cada 15 minutos durante 2 horas. Foi considerada má absorção quando houve incremento $>20$ ppm de hidrogênio no ar expirado em relação ao jejum, e intolerância caso surgissem sintomas após a sobrecarga. Resultados - A idade dos pacientes variou de 3 meses a 16 anos, 24 meninos. Foram estabelecidos os seguintes diagnósticos: síndrome do intestino irritável com diarréia 16, dor abdominal funcional 8, baixa estatura 10, intolerância à lactose 3, doença celíaca 1, alergia alimentar 1 e giardíase 1 . Má-absorção à frutose foi caracterizada em 13 (30,2\%) pacientes; observou-se intolerância em 1 (2,3\%) deles. Síndrome do intestino irritável com diarréia em 7 (16,3\%) e dor abdominal funcional em 4 (9,3\%) pacientes foram os transtornos com maior prevalência responsáveis pela má absorção à frutose. Conclusãa - Síndrome do intestino irritável seguida de dor abdominal funcional mostraram-se como as principais causas da elevada freqüência de má absorção à frutose seguida de dor abdominal funcional, porém, sem que houvesse correspondente intolerância, provavelmente devido a um mecanismo de compensação colônica.

DESCRITORES - Frutose, deficiencia. Absorção intestinal. Testes respiratórios. Criança. 


\section{REFERENCES}

1. Agriculture Research Service. Food and Nutrient Intakes by Individuals in the United States by Sex and Age, 1994-96. Washington DC. US Department of Agriculture; 1998. NFS Report n 96-2.

2. Choi YK, Johlin FC Jr, Summers RW, Jackson M, Rao SS. Fructose intolerance: an under-recognized problem. Am J Gastroenterol 2003;98:1348-53.

3. Committee on Nutrition. American Academy of Pediatrics: The use and misuse of fruit juice in pediatrics. Pediatrics 2001;107:1210-13.

4. Doma S, Gaddipati K, Fernandez A. Results of fructose breath test in healthy controls using different doses of fructose: which dose is best? Am J Gastroenterol 2003; 98: s265-6.

5. Duro D, Rising R, Cedillo M, Lifshitz F. Association between infantile colic and carbohydrate malabsorption from fruit juice in infancy. Pediatrics. 2002;109:797-805.

6. Eisenmann A, Amann A, Said M Datta B, Ledochowski M. Implemetaiton and interpretation of $\mathrm{H} 2$ breath tests. J Breath Res. 2008;2:1-9.

7. Gijsbers CFM, Kneepkens CMF, Buller HA. Lactose and frutose malabsorption in children with recurrent abdominal pain: results of double-blinded testing Acta Paediatrica. 2012;101:411-15.

8. Gomara RE, Halata MS, Newman LJ, Bostwick HE, Berezin SH, Cukaj L, See MC, Medow MS. Fructose intolerance in children presenting with abdominal pain. J Pediatr Gastroenterol Nutr. 2008;47:303-8.

9. Hoekstra JH, Van Kempen AA, Bijl SB, Kneepkens CM. Fructose breath Hydrogen tests. Arch Dis Child. 1993;68:136-8.

10. Hyams JS, Etienne NL, Leichtner AM, Theuer RC. Carbohydrate malabsorption following fruit juice ingestion in young children. Pediatrics. 1988;82:64-8.

11. Johlin FC, Panther M, Kraft N. Dietary fructose intolerance: diet modification can impact self-rated health and symptom control. Nutr Clin Care 2004;7:92-7

12. Jones HF, Burt E, Dowling K, Davidson G, Brooks D, Butler RN. Effect of age on fructose malabsorption in children presenting with gastrointestinal symptoms. J Pediatr Gastroenterol Nutr. 2011;52:581-84.

13. Jones HF, Butler RN, Brooks DA. Intestinal fructose transport and malabsorption in humans. Am J Physiol Gastrointest Liver Physiol 2011;300:g202-6.

14. Ledochowsky M, Widner B, Bair H Probst T, Fuchs D. Fructose and sorbitol reduced diet improves mood and gastrointestinal disturbances in fructose malabsorbers. Scand J Gastroentrol. 2000;35:1048-52.
15. Lifshtz F, Ament ME, Kleinman RE, Klish W, Lebenthal E, Pearman J, Udall JN Jr. Role of juice carbohydrate malabsorption in chronic nonspecific diarrhea in children. J Pediatr. 1992;120:825-9.

16. Mishkin D, Sabrauskas L, Yalovsky M, Mishkin S. Fructose and sorbitol malabsorption in ambulatory patients with functional dyspepsia: comparison with lactose maldigestion/malabsorption. Dig Dis Sci. 1997;42:2591-8.

17. Nobigrot T, Chasalow FI, Lifshitz F. Carbohydrate absorption from one serving of fruit juice in young children: age and carbohydrate composition effects. J Am Coll Nutr. 1997;16:152-58.

18. Physical status: the use and interpretation of anthropometry Report of a WHO Expert Committee. World Health Organ Tech Rep Ser. 1995;854:1-452.

19. Rasquin A, Di Lorenzo C, Forbes D, Guiraldes E, Hyams JS, Staiano A, Walker LS. Childhood functional gastrointestinal disorders: child/adolescent. Gastroenterology. 2006;130:1527-37.

20. Ribes-Koninckx C, Mearin ML, Korponay-Szabó IR, Shamir R, Husby S, Ventura A, Branski D, Catassi C, Koletzko S, Mäki M, Troncone R, Zimmer KP; ESPGHAN Working Group on Coeliac Disease Diagnosis. Coeliac disease diagnosis: ESPGHAN 1990 criteria or need a change? Results of a questionnaire. J Pediatr Gastroenterol Nutr. 2012;54:15-9.

21. Riby JE, Fujisaswa T, Kretchmer N. Fructose absorption. Am J Clin Nutr 1993;58:S748-53.

22. Romagnuolo J, Schiller D, Bailey RJ. Using breath tests wisely in a gastroenterology practice: an evidence-based reviewof indications and pitfalls in interpretation. Am J Gastroenterology. 2002;97:1113-26.

23. Rumessen JJ, Gudmannd-Hoyer E. Functional bowel disease: malabsorption and abdominal distress after ingestion of fructose, sorbitol, and fructose-sorbitol mixtures. Gastroenterology. 1988;95:694-700.

24. Shi X, Schedl HP, Summers RM, Lambert GP, Chang RT, Xia T, Gisolfi CV. Fructose transport mechanisms in humans. Gastroenterology. 1997;113:1171-9.

25. Smith MM, Davis M, Chasalow FI, Lifshitz F. Carbohydrate absorption from fruit juice in young children. Pediatrics 1995;95:340-44.

Received 27/2/2013 Accepted 26/6/2013 